\title{
Defective Leukocyte Fungicidal Activity in End-Organ Resistance to 1,25-Dihydroxyvitamin D
}

\author{
A. ETZIONI, Z. HOCHBERG, S. POLLAK, T. MESHULAM, V. ZAKUT, E. TZEHOVAL,
} Y. KEISARI, I. AVIRAM, Z. SPIRER, A. BENDERLY, AND Y. WEISMAN

Department of Pediatrics, Rambam Medical Center, Faculty of Medicine, Technion Institute of Technology, Haifa [A.E., Z.H., S.P., T.M., A.B.] Department of Pediatrics, Tel-Aviv Medical Center [Y.W., Z.S.], Department of Microbiology, Sackler School of Medicine [Y.K.], the Department of Biochemistry, Tel-Aviv University [I.A.], and the Department of Cell Biology, The Weizmann Institute of Science, Rehovot, Israel [E.T.]

\begin{abstract}
Recent studies have shown 1,25(OH) $)_{2}$ receptor-mediated modulation of leukocyte proliferation, differentiation, and function. We examined the phagocytosis and killing of microorganisms by neutrophils and monocytes from five patients of three families with hereditary resistance to $1,25(\mathrm{OH})_{2} \mathrm{D}_{3}$. Phagocytosis of microorganisms by patients' neutrophils and monocytes was normal. However, defective neutrophil killing activity toward Candida albicans (30-40\% of controls) was found in all patients. The killing of Staphylococcus aureus was normal. The neutrophil chemiluminescence, nitroblue tetrazolium (NBT) dye reduction, and the generation of superoxide ions and hydrogen peroxide by neutrophils and monocytes after induction by either soluble stimuli or zymozan particles, did not differ from those in controls. The neutrophil myeloperoxidase activity was also normal. Monocytes obtained from two patients of different families before long-term calcium infusion therapy and after they became normocalcemic, demonstrated a similar impaired fungicidal activity toward Saccharomyces cerevisiae, indicating that hypocalcemia itself was not the cause of the killing defect. However, the addition of the $\mathrm{Ca}^{+2}$ ionophore $\mathrm{A} 23187(1 \mu \mathrm{M})$ to the test medium restored the monocyte fungicidal activity to normal. As patients' neutrophil cytosolic free calcium concentration was similar to that in controls, it is suggested that $1,25-(\mathrm{OH})_{2} \mathrm{D}_{3}$ exerts its effect on leukocyte function by a putative receptor-mediated regulation of subcellular calcium localization which may be important for fungicidal activity. (Pediatr Res 25:276-279, 1989)
\end{abstract}

\section{Abbreviations}

$1,25(\mathrm{OH})_{2} \mathrm{D}_{3}, 1,25$-dehydroxyvitamin $\mathrm{D}_{3}$ TPA, 12- $O$-tetra-decanoyl-phorbol-13-acetate f-met-leu-phe, $\mathrm{N}$-formyl-L-methionyl-L-phenylalanine NBT, nitroblue-tetrazolium

Recently, it has been shown that receptors for $1,25-(\mathrm{OH})_{2} \mathrm{D}_{3}$, the hormonal form of vitamin $D_{3}$, are present in cellular components of the immune system and that specific functional receptors for $1,25-(\mathrm{OH})_{2} \mathrm{D}_{3}$ mediate the effects of $1,25-(\mathrm{OH})_{2} \mathrm{D}_{3}$

Received December 11, 1986; accepted November 3, 1988.

Correspondence Dr. Y. Weisman, Bone Disease Unit, Ichilov Hospital, 6 Weizmann Street, Tel-Aviv 64239, Israel. on the proliferation and differentiation of these cells (1-4). Previous observations have reported that vitamin $\mathrm{D}$ deficiency is associated with reduced neutrophil motility (5) and impaired phagocytosis (6). Moreover, impaired function of macrophages in vitamin $\mathrm{D}$-deficient mice was corrected in vitro by 1,25 $(\mathrm{OH})_{2} \mathrm{D}_{3}(7)$. The occurrence of the syndrome of end-organ resistance to $1,25-(\mathrm{OH})_{2} \mathrm{D}_{3}$ due to defective receptors or lack of biologic response to $1,25-(\mathrm{OH})_{2} \mathrm{D}_{3}(8)$ provides an unusual opportunity of investigating the functions of $1,25-(\mathrm{OH})_{2} \mathrm{D}_{3}$ in the immune system of the human subject. Indeed, peripheral blood mononuclear cells of patients with resistance to $1,25-(\mathrm{OH})_{2} \mathrm{D}_{3}$ did not acquire receptors for $1,25-(\mathrm{OH})_{2} \mathrm{D}_{3}$ after lectin stimulation as normal mononuclear cells do. Furthermore, in contrast to its effects on normal lymphocytes, $1,25-(\mathrm{OH})_{2} \mathrm{D}_{3}$ failed to inhibit the proliferation of lectin-stimulated lymphocytes from patients with resistance to $1,25-(\mathrm{OH})_{2} \mathrm{D}_{3}(9)$. In this study, we report our observations on the phagocytosis and intracellular killing of microorganisms by neutrophils and monocytes from five of the same group of patients.

\section{PATIENTS AND METHODS}

Five patients (four boys and one girl) aged 2 to $11 \mathrm{y}$ of three families were studied. The patients had typical features of endorgan resistance to $1,25-(\mathrm{OH})_{2} \mathrm{D}_{3}(10,11)$ including rickets, alopecia, hypocalcemia, high serum $1,25-(\mathrm{OH})_{2} \mathrm{D}_{3}$ levels and resistance to treatment with vitamin $\mathrm{D}_{3}$ or $1,25-(\mathrm{OH})_{2} \mathrm{D}_{3}$. Defective receptors for $1,25-(\mathrm{OH})_{2} \mathrm{D}_{3}$ in cultured skin fibroblasts and lectin-stimulated peripheral blood mononuclear cells were demonstrated in all patients. Details of the receptor studies and patients' clinical and biochemical features are documented in previous reports $(9,11-13)$. Table 1 shows the main biochemical data at the time that the present tests were performed. Children admitted to the hospital for minor surgery served as controls. Informed consent was obtained from the parents of all children.

Neutrophils and mononuclear cells were isolated from heparinized venous blood by standard Ficoll-Hypaque gradients and dextran sedimentation techniques (14). Monocytes in the mononuclear cell fraction were allowed to adhere to plastic culture plates for $1 \mathrm{~h}$ in RPMI 1640 medium with $30 \%$ FCS. After washings to remove nonadherent cells, the adherent population was found to be greater than $95 \%$ monocytes as judged by the Wright-Giemsa stain. The phagocytosis and intracellular killing of Candida albicans and Saccharomyces cerevisiae were measured by the assay of Leherer and Cline (15), based on the differential staining of nonviable microorganisms by methylene blue. The phagocytosis and intracellular killing of Staphylococcus aureus were measured by the $\left[{ }^{3} \mathrm{H}\right]$ uridine incorporation radio- 
Table 1. Biochemical findings at time that present studies were performed

\begin{tabular}{lllcc}
\hline Patients & $\begin{array}{c}\mathrm{Ca} \\
(\mathrm{mg} / \mathrm{dl})\end{array}$ & $\begin{array}{c}\mathrm{Pi} \\
(\mathrm{mg} / \mathrm{dl})\end{array}$ & $\begin{array}{c}\text { Alkaline phosphatase } \\
(\mathrm{IU} / \mathrm{ml})\end{array}$ & $\begin{array}{c}1,25(\mathrm{OH})_{2} \mathrm{D}_{3} \\
(\mathrm{pg} / \mathrm{ml})\end{array}$ \\
\hline 1 & $5.7-9.7^{*}$ & $3.2-4.6^{*}$ & $1600-350^{*}$ & $>600-88^{*}$ \\
2 & $7.1-9.4^{*}$ & $3.8-4.5^{*}$ & $900-300^{*}$ & $>600-96^{*}$ \\
3 & 6.5 & 4.3 & 990 & 280 \\
4 & 7.0 & 3.9 & 1900 & 220 \\
5 & 7.1 & 3.4 & 2000 & 180 \\
Normal range & $8.5-10.2$ & $4.4-6$ & $100-200$ & $30-80$ \\
\hline
\end{tabular}

* Patient was studied before and during long-term calcium infusion therapy.

metric assay as previously described $(16,17)$. The assay depends upon the fact that external viable microorganisms incorporate $\left[{ }^{3}\right.$ H] uridine, whereas those that are ingested by leukocytes do not. Briefly, $1 \times 10^{6}$ neutrophils were mixed with $1 \times 10^{7} \mathrm{~S}$. aureus in $1 \mathrm{ml}$ of RPMI 1640 medium with $5 \%$ normal human serum in small tubes and rotated end over end at $30 \mathrm{rpm}$ at $37^{\circ} \mathrm{C}$ for $30 \mathrm{~min}$. Controls lacking either $S$. aureus or neutrophils were also prepared. Phagocytosis was measured by taking a $100-\mu 1$ aliquot from each tube to tubes containing $0.2 \mu \mathrm{Ci}$ of $\left[{ }^{3} \mathrm{H}\right]$ uridine (Sp act $5 \mu \mathrm{Ci} / \mathrm{mmol}$ Amersham Laboratories, Buckinghamshire, England) in $100 \mu \mathrm{l}$ of medium. The tubes were then incubated at $37^{\circ} \mathrm{C}$ for $60 \mathrm{~min}$. Intracellular killing was measured by taking a 100- $\mu$ l aliquot from each tube into tubes containing $0.2 \mu \mathrm{Ci}$ $\left[{ }^{3} \mathrm{H}\right]$ uridine, and the leukocytes were lysed in sodium deoxycholate $(0.6 \%)$ plus DNAse (Sigma Chemicals Co., St. Louis, MO). The contents of the tubes were filtered through a membrane (Sartorius $0.45 \mu \mathrm{m}$, Sartorius Filters, Inc., Haywood, CA), washed three times, and dried for $2 \mathrm{~h}$ at $37^{\circ} \mathrm{C}$. Associated radioactivity was measured in a liquid scintillation spectrometer. The percentage of ingested bacteria was calculated from the difference in the incorporation of $\left[{ }^{3} \mathrm{H}\right]$ uridine into $S$. aureus in the presence or absence of leukocytes. The percentage of bacteria killed was calculated from the number of viable microorganisms added by lysis of the leukocytes to those not phagocytosed. This value was used to calculate the percentage of phagocytosed bacteria killed.

The endotoxin-stimulated NBT test was performed as described $(18,19)$.

The neutrophil Luminol-dependent chemiluminescence response to TPA (Sigma) was measured with a LKB-Wallac 1250 luminometer (LKB, Wallac, Finland). Leukocyte suspensions were prepared by hypotonic lysis of the red blood cells in $0.5-\mathrm{ml}$ samples of heparinized blood. A leukocyte suspension of $100 \mu 1$ $\left(\sim 5 \times 10^{6}\right.$ cells $)$ was placed into the luminometer in the presence of TPA $\left(5 \times 10^{-6} \mathrm{M}\right)$ and $10^{-5} \mathrm{M}$ Luminol (3-aminophthalhydrazide, Sigma). The results are expressed as light intensity in $\mathrm{mV} / 5 \times 10^{6}$ cells. Production of superoxide $\left(\mathrm{O}_{2}^{-}\right)$in neutrophils and monocytes was assayed by the superoxide dismutase inhibitable reduction of cytochrome $C(20,21)$. The neutrophils or monocytes were stimulated by either $100-n M$ TPA (Sigma) or by serum-opsonized zymozan particles $(0.5 \mathrm{mg} / \mathrm{ml}$, Sigma) for $60 \mathrm{~min}$ or by f-met-leu-phe $\left(5 \times 10^{-7} \mathrm{M}\right.$, Sigma $)$ for $5 \mathrm{~min}$. The results are expressed as $n m o l \mathrm{O}_{2}{ }^{-}$produced during the incubation time $/ 10^{6}$ cells. $\mathrm{H}_{2} \mathrm{O}_{2}$ production by polymorphonuclear leukocytes and monocytes was quantitated according to Pick and Keisari (22), using a method which is based on the $\mathrm{H}_{2} \mathrm{O}_{2}$ mediated and horseradish peroxidase-dependent oxidation of phenol red to a product whose absorbance is read at $610 \mathrm{~nm}$. The results were expressed as $\mathrm{nmol} \mathrm{H}_{2} \mathrm{O}_{2}$ produced by $10^{6}$ cells in $60 \mathrm{~min}$. The assay for myeloperoxidase activity involves following the change in absorbance at $450 \mathrm{~nm}$ that accompanies the oxidation of $O$-dianisidine $\left(3.3^{\prime}\right.$-dimethoxybenzidene; Sigma) (23). The results were expressed as nmol of dianisidine oxidized by $10^{6}$ cells in $1 \mathrm{~min}$.

The cytosolic free calcium concentration of neutrophils obtained from one patient was measured by using the fluorescent
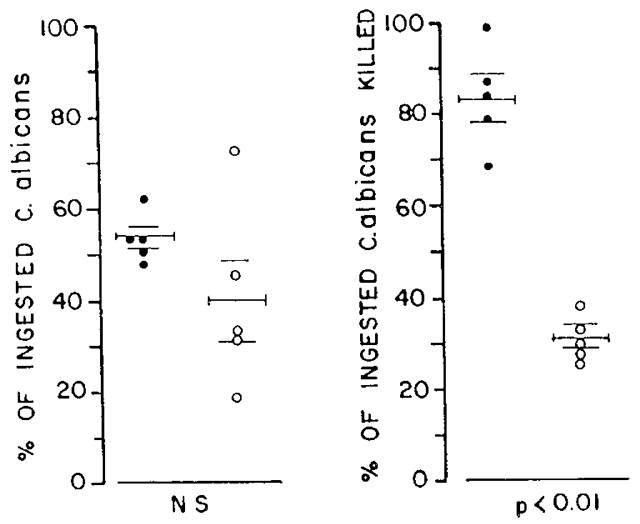

Fig. 1. Neutrophil phagocytic and killing activities towards C. albicans in five patients with end-organ resistance to $1,25(\mathrm{OH})_{2} \mathrm{D}_{3}$ and in five controls. For experimental details, see "Patients and Methods." $O$, patients; $\bullet$ controls; - , means \pm SEM.

calcium indicator Quin-2 as previously described (24). In neutrophils from anothr patient, the free calcium concentration was measured using the calcium indicator fura-AM (Molecular Probs, Junction City, OR). Neutrophil $\left(5 \times 10^{7} / \mathrm{ml}\right)$ cells were incubated with $5-\mu \mathrm{M}$ fura-AM for $12 \mathrm{~min}$ and then diluted with $4 \mathrm{vol}$ of buffer. After $30 \mathrm{~min}$, the cells were pelleted, and fluorescence was measured in the 44B Perkin Elmer spectrofluorometer as described by Grynkiewicz et al. (25).

\section{RESULTS}

Fungicidal activity. The neutrophil candidacidal activity was significantly lower in patients with resistance to $1,25-(\mathrm{OH})_{2} \mathrm{D}_{3}$ $(31.3 \pm 2.2 \%$ of ingested $C$. albicans was killed in $1 \mathrm{~h})$ than in controls $(82.8 \pm 5.1 \%)$ (Fig. 1). Similarly, the ability of peripheral blood monocytes from two patients to kill $S$. cerevisiae was lower than in controls (Table 2). To rule out the possibility that hypocalcemia per se is the cause of the impaired killing of yeasts, the patients were studied again while on long-term intracaval calcium infusions and normocalcemic (26). The results showed that normocalcemia could not correct the impaired monocyte killing of yeast (Table 2). However, the presence of the calcium ionophore A $23187(1 \mu \mathrm{M})$ in the test medium restored the monocyte-killing activity towards $S$. cerevisiae to normal (Table 2). A $23187(1 \mu \mathrm{M})$ did not increase the killing of $S$. cerevisiae in monocytes from controls and had no direct effect on the viability of $S$. cerevisiae in the test medium.

Bactericidal activity. In contrast to their impaired fungicidal activity, the ability of the patients' neutrophils to kill ingested $S$. aureus did not differ from that found in controls (killing index, $107.6 \pm 5.1 \%$ of controls).

Phagocytic activity. The neutrophil ingestion of $C$. albicans (Fig. 1) and the monocyte phagocytosis of $S$. cerevisiae $(47.7 \pm$ $3.8 \%$ of $S$. cerevisiae ingested in $1 \mathrm{~h}$ versus $51.4 \pm 3.4 \%$ in controls) were comparable to those found in controls. Similarly, the ability of neutrophils to ingest $S$. aureus was normal (47.3 \pm $2.5 \% \mathrm{~S}$. aureus ingested in $1 \mathrm{~h}$ versus $44.6 \pm 3.0 \%$ in controls).

The endotoxin-stimulated NBT test was normal in neutrophils of all patients ( $>40 \%$ NBT-positive cells).

The chemiluminescence response of leukocytes from three patients to TPA stimualtion $(58-78 \mathrm{mV})$ did not differ from the responses recorded in leukocytes of controls (54-98 mV). Incubation of neutrophils and monocytes obtained from one patient with either TPA or serum-opsonized zymozan resulted in the generation and release of superoxide, which did not differ from that observed in controls (Table 3). Similarly, neutrophils obtained from another patient that were stimulated by f-met-leuphe generated $21 \pm 0.8 \mathrm{nmol} / 10^{6} \mathrm{cell} / 5 \mathrm{~min}$ of $\mathrm{O}_{2}{ }^{-}$as compared to $18.4 \pm 0.8 \mathrm{nmol} / 10^{6} \mathrm{cell} / 5 \mathrm{~min}$ in controls. The production 
Table 2. Monocyte killing activity in end-organ resistance to $1,25(\mathrm{OH})_{2} \mathrm{D}_{3}$ in two patients examined before and after intracaval $\mathrm{Ca}^{2+}$ infusion and in six controls in three to five experiments

\begin{tabular}{|c|c|c|c|}
\hline \multirow[t]{2}{*}{ Treatment } & \multicolumn{3}{|c|}{$\begin{array}{l}\text { Killing activity (\% of ingested) } \\
\text { S. cerevisiae killed in } 1 \mathrm{~h} \text {; mean } \pm \text { SEM) }\end{array}$} \\
\hline & Patient 1 & Patient 2 & Controls \\
\hline Hypocalcemia (no treatment) & $19.8 \pm 2.3^{*}$ & $21.3 \pm 3.1^{*}$ & $47.2 \pm 1.9$ \\
\hline Normocalcemia (intravenous calcium) $\dagger$ & $20.1 \pm 2.4^{*}$ & $22.1 \pm 2.8^{*}$ & $48.9 \pm 2.0$ \\
\hline $\begin{array}{l}\text { Normocalcemia (intravenous calcium) + cal- } \\
\text { cium ionophore-A } 23187(1 \mu \mathrm{M}) \S\end{array}$ & $48.5 \pm 2.5 \neq$ & $49.3 \pm 3.0 \div$ & $48.7 \pm 2.5$ \\
\hline $\begin{array}{l}\text { Normocalcemia (intravenous calcium) + A } \\
23187(0.1 \mu \mathrm{M})\end{array}$ & $36.3 \pm 1.9^{*} \ddagger$ & $35.7 \pm 2.4^{*}+$ & $48.7 \pm 2.5$ \\
\hline
\end{tabular}

* Different from controls, $p<0.01$.

$\dagger$ Normocalcemia was achieved in the patients following long-term intracaval calcium infusions. (See "Patients and Methods.")

$\ddagger$ Different from patients' monocytes not treated with A 23187, $p<0.01$.

$\S$ The calcium ionophore was added to the killing test medium. (See "Patients and Methods.")

of $\mathrm{H}_{2} \mathrm{O}_{2}$ in neutrophils $\left(38 \pm 1 \mathrm{nmol} / 10^{6}\right.$ cells $\left./ 60 \mathrm{~min}\right)$ and monocytes $\left(13 \pm 1 \mathrm{nmol} / 10^{6}\right.$ cells $\left./ 60 \mathrm{~min}\right)$ after TPA stimulation, also did not differ from controls $\left(39 \pm 1 \mathrm{nmol} / 10^{6} \mathrm{cells} / 60\right.$ min and $14 \pm \mathrm{nmol} / 10^{6}$ cells $/ 60 \mathrm{~min}$, respectively). The myeloperoxidase activity measured in neutrophils from two patients was 425 and $470 \mathrm{nmol}$ of dianisidine oxidized $/ \mathrm{min}$ in $10^{6}$ cells. These results did not differ from those recorded in controls (460 $\pm 40 \mathrm{nmol} / 10^{6} \mathrm{cells} / \mathrm{min}$ ). The release of myeloperoxidase following f-met-leu-phe-induced degranulation of neutrophils from both patients and controls was $16-25 \%$ of the total myeloperoxidase activity.

The cytosolic free calcium concentration measured in neutrophils of one patient by using the fluorescent calcium indicator Quin-2 was $112 \pm 9 \mathrm{nM}$ as compared to $122 \pm 14 \mathrm{nM}$ in controls. In another patient, the free calcium concentration measured by the calcium indicator fura- $2 \mathrm{AM}$ was $160 \mathrm{nM}$ as compared to $172-181 \mathrm{nM}$ in controls.

\section{DISCUSSION}

The present study demonstrates an impaired leukocyte fungicidal activity in patients with end-organ resistance to 1,25$(\mathrm{OH})_{2} \mathrm{D}_{3}$. Our study indicates that only a fraction of the processes of intracellular killing of microorganisms is impaired. The adequacy of the remaining mechanisms is indicated by the normal bactericidal activity toward $S$. aureus and the fact that our patients are not troubled by recurrent serious infections. There could be an analogy with the condition of hereditary myeloperoxidase deficiency in which there is an impairment mainly in the candidacidal activity, which similarly does not cause a tendency to infection (27). However, the myeloperoxidase activity in neutrophils of patients with resistance to $1,25-(\mathrm{OH})_{2} \mathrm{D}_{3}$ did not differ from that recorded in controls. Production of superoxide and hydrogen peroxide by monocytes and neutrophils as well as the chemiluminescence responses of the patient's leukocytes to TPA were also comparable to results recorded in controls. These results suggest that an impairment in the oxidative burst mechanism is not the cause of the fungicidal defect in our patients.

The mechanism that links the observed defect of intracellular killing activity to the lack of normal receptors for $1,25-(\mathrm{OH})_{2} \mathrm{D}_{3}$, is not known at present. The absence of normal $1,25-(\mathrm{OH})_{2} \mathrm{D}_{3}$ receptors in the intestine results in impaired calcium absorption and hypocalcemia. However, hypocalcemia per se is probably not the cause of the impaired killing activity, as normalization of serum calcium levels could not correct the defect. It is reasonable to assume that the lack of $1,25-(\mathrm{OH})_{2} \mathrm{D}_{3}$ receptors in the leukocytes is linked to the observed intracellular killing defect. There are three likely explanations: The first is that since 1,25$(\mathrm{OH})_{2} \mathrm{D}_{3}$ may play a role in the differentiation of leukocyte precursors $(28,29)$, the cells of these patients may not be fully mature and lack a normal killing mechanism. The second possibility is that $1,25-(\mathrm{OH})_{2} \mathrm{D}_{3}$ regulates the synthesis of enzymes or other proteins which are concerned in the killing activity. The
Table 3. Superoxide ion $\left(\mathrm{O}_{2}^{-}\right)$production by neutrophils and monocytes in hereditary resistance to $1,25(\mathrm{OH})_{2} \mathrm{D}_{3}$

\begin{tabular}{|c|c|c|c|c|c|}
\hline & \multicolumn{5}{|c|}{$\mathrm{nmol} / 10^{6}$ cells $/ 60 \mathrm{~min}$} \\
\hline & \multirow{2}{*}{$\begin{array}{l}\text { TPA (100 nM) } \\
\text { Neutrophils }\end{array}$} & \multicolumn{2}{|c|}{ Zymozan $(0.5 \mathrm{mg} / \mathrm{ml})$} & \multicolumn{2}{|c|}{ Control (unstimulated) } \\
\hline & & Monocytes & Neutrophils & Monocytes & Neutrophils \\
\hline Patient 1 & $32 \pm 4$ & $35 \pm 5$ & $34 \pm 4$ & $13 \pm 1$ & $4 \pm 0.3$ \\
\hline Control 1 & $22 \pm 3$ & $45 \pm 2$ & $32 \pm 2$ & $15 \pm 0$ & $4 \pm 0.3$ \\
\hline Control 2 & $19 \pm 2$ & $35 \pm 5$ & $38 \pm 2$ & $12 \pm 2$ & $3 \pm 0.2$ \\
\hline
\end{tabular}

third possibility is that $1,25-(\mathrm{OH})_{2} \mathrm{D}_{3}$ affects the killing activity through its effect on the synthesis of proteins which regulate intracellular calcium metabolism. The observation that the calcium ionophore A 23187 restored the monocyte killing activity to normal makes the first two possibilities unlikely and suggests that the intracellular killing of yeast is dependent on normal redistribution of intracellular calcium, which is probably regulated by the $1,25-(\mathrm{OH})_{2} \mathrm{D}_{3}$ receptor-effector system. Confirmation of the latter hypothesis would require the identification of the putative $1,25-(\mathrm{OH})_{2} \mathrm{D}_{3}$-induced protein(s) and a demonstration of its importance to the killing process.

Acknowledgment. The authors thank Dr. Zvi Naor and Prof. R. Chayen for their advice and help.

\section{REFERENCES}

1. Manolagas SC, Deftos LJ 1984 The vitamin D endocrine system and the hematolymphopoietic tissue. Ann Intern Med 100:144-146

2. Editorial 1984 Vitamin D and the lymphomedullary system. Lancet 1:11051106

3. Provvedini DM, Tsoukas CD, Deftos LJ, Manolagas SC 1083 1,25-dihydroxyvitamin $\mathrm{D}_{3}$ receptors in human leukocytes. Science 221:1181-1183

4. Bhalla AK, Amento EP, Clemens TL, Hollick MF 1983 Specific high-affinity receptors for 1,24-dihydroxyvitamin $\mathrm{D}_{3}$ in human peripheral blood mononuclear cells: presence in monocytes and induction in T lymphocytes following activation. J Clin Endocrinol Metab 57:1308-1310

5. Lorente F, Fontan G, Jara P, Casas C, Garcia-Rodriguez MC, Ojeda JA 1976 Defective neutrophil motility in hypovitaminosis D rickets. Acta Paediatr Scand 65:695-699

6. Stroder J, Kasal P 1970 Evaluation of phagocytosis in rickets. Acta Paediatr Scand 59:288-292

7. Bar-Shavit Z, Noff D, Edelstein S, Meyer M, Shibolet S, Goldman R 1981 1,25-dihydroxyvitamin $\mathrm{D}_{3}$ and the regulation of macrophage function. Calcif Tissue Int 33:673-676

8. Liberman UA, Eil C, Marx SJ 1983 Resistance to 1,25-dihydroxyvitamin D: association with heterogeneous defects in cultured skin fibroblasts. J Clin Invest 71:192-200

9. Koren R, Ravid A, Liberman UA, Hochberg Z, Weisman Y, Novogrodsky A 1985 Defective binding and function of 1,25-dihydroxyvitamin $D_{3}$ receptors in peripheral mononuclear cells of patients with end-organ resistance to 1,25-dihydroxyvitamin D. J Clin Invest 76:2012-2015

10. Rosen JF, Fleishman AR, Finberg L, Hamstra A, DeLuca HF 1979 Rickets with alopecia: an inborn error of vitamin D metabolism. J Pediatr 94:729735

11. Hochberg Z, Benderli A, Levy J, Vardi P, Weisman Y, Chen T, Feldman D 1984 1,25-dihydroxyvitamin D resistance, rickets and alopecia. Am J Med $77: 805-811$ 
12. Feldman D, Chen T, Cone C, Hirst M, Shani S, Benderli A, Hochberg Z 1982 Vitamin D-resistance rickets with alopecia: cultured skin fibroblasts exhibit defective cytoplasmic receptors and unresponsiveness to $1,25(\mathrm{OH})_{2} \mathrm{D}_{3}$. J Clin Endocrinol Metab 55:1020-1022

13. Hochberg Z, Borochowitz Z, Benderli A, Vardi P, Oren S, Spirer Z, Heyman I, Weisman Y 1985 Does 1,25-dihydroxyvitamin D participate in the regulation of hormone release from endocrine glands? J Endocrinol Metab 60:5761

14. Boyum A 1974 Separation of blood leucocytes, granulocytes and lymphocytes. Tissue Antigens 4:269-274

15. Lehrer RI, Cline MU 1969 Interaction of C. albicans with human leukocytes and serum. J Bacteriol 98:996-1004

16. Lam C, Mathison GE 1979 Phagocytosis measured as inhibition of uridine uptake: a method that distinguishes between surface adherence and ingestion. J Med Microbiol 12:459-467

17. Banks RM, O'Grady F 1983 Therapeutic significance of nocardicin: a stimulation of phagocyte function in experimental pseudomonas aeruginosa infection. Br J Exp Pathol 65:231-237

18. Humbert JR, Marks MI, Hathaway WE, Thoren CH 1971 The histochemical nitroblue tetrazolium reduction test in the differential diagnosis of acute infections. Pediatrics 48:259-267

19. Park BH, Good RA 1970 NBT test stimulated. Lancet $2: 616$

20. Babior BM, Kipnes R, Curnette JT 1973 Biological defence mechanisms: the production by leukocytes of superoxide, a potential bactericidal agent. J Clin Invest $52: 741-744$
21. Keisari X, Braun L, Flescher E 1983 The oxidative burst and related phenomena in mouse macrophages elicited by different inflammatory stimuli. Immunobiology 165:78-89

22. Pick E, Keisari Y 1980 A simple colorimetric method for the measurement of hydrogen peroxide produced by cells in culture. $\mathrm{J}$ Immunol Methods $38: 161$ 171

23. Babior BM, Cohen HJ 1981 In: Cline MY (ed) Methods of Hematol, vol 3. Churchill Livingstone, New York, pp 1-38

24. Bar S, Lidor C, Hareil A, Edelstein S 1986 Influence of 1,25-dihydroxyvitamin $\mathrm{D}_{3}$ on cytosolic free calcium concentration. Biochem Biophys Res Commun 141:1236-1241

25. Grynkiewicz G, Poeni M, Tsien RY 1985 A new generation of $\mathrm{Ca}^{+2}$ indicators with greatly improved fluorescence properties. J Biol Chem 260:3440-3450

26. Weisman Y, Bab I, Gazit D, Spirer Z, Jaffe M, Hochberg Z 1987 Long-term intracaval calcium infusion therapy in end-organ resistance to 1.25-dihydroxyvitamin D. Am J Med 83:984-990

27. Parry MF, Root RK, Metcalf JA, Delaney KK, Kaplow LS, Richar WJ 1981 Myeloperoxidase deficiency: prevalence and clinical significance. Ann Intern Med 95:293-301

28. Abe E, Miyauza C, Sakagami H, Takeda M, Yamazaki T, Yoshiki S, Suda T 1981 Differentiation of mouse myeloid leukemia cells induced by 1,25 dihydroxyvitamin D. Proc Natl Acad Sci USA 78:4990-4994

29. Bar-Shavit Z, Teitelbaum SL, Retisma P, Hall A, Pegg LE, Trial J, Kahn AJ 1983 Induction of monocytic differentiation and bone resorption by 1,25 . dihydroxyvitamin $\mathrm{D}_{3}$. Proc Natl Acad Sci USA 80:5907-5911

\section{Announcements}

\section{Annual Meetings}

The American Pediatric Society, the Society for Pediatric Research, and the Ambulatory Pediatric Association will have meetings on May 1-5, 1989 at the Washington Sheraton Hotel, Washington, D.C.

Contact: SPR-Ms. Debbie Wogenrich, 2650 Yale Blvd., S.E., Suite 104, Albuquerque, NM 87106 (505)7649099. APS-Dr. Audrey K. Brown, Secretary-Treasurer, Department of Pediatrics, SUNY, Health Science Center at Brooklyn, 450 Clarkson Avenue, Box 49, Brooklyn. NY 11203 (718)270-1692. APA-Ambulatory Pediatric Association, 6728 Old McLean Village, McLean, VA 22101 (703)556-9222.

\section{Annual Meeting of the European Society for Pediatric Research}

The Annual Meeting of the European Society for Pediatric Research will be held in Kraków, Poland, June 1114 1989. In addition to free paper and poster sessions, plenary sessions and workshops will be held on topics including acute renal failure, advances in genetics and immunology, applied genetics, perinatal epidemiology, neonatology, diabetes, and atrial natriuretic peptides. European Working Groups on Allergy and Clinical Immunooogy, Mineral Metabolism. Neonatogy and Perinatal and Pediatric Microcirculation will participate. Deadline for receipt of abstracts will be January 311989.

For abstract forms and information contact the President of the Meeting: Jacek J. Pietrzyk, 1st Department of Pediatrics. Institute of Pediatrics, 30-663 Kraków, Wielicka 265, Poland, phone 55-02-56, telex 032-5795 IP AM PL. 